\title{
Pengaruh Waktu dan Jarak Electroplating Nikel pada Baja Karbon Rendah Terhadap Kekerasan Permukaan
}

\section{Effect of time and distance of nickel electroplating on low carbon steel against surface hardness}

\author{
S. Salman*, I.M.A. Sayoga, I.D.K. Okariawan, S. Sinarep, R. Sutanto, A. Wiranata \\ Jurusan Teknik Mesin, Fakultas Teknik, Universitas Mataram, Jl. Majapahit No.62 Mataram NTB, \\ 83125, Indonesia. HP. 087765542332 \\ *Email : salmanrm@yahoo.ac.id
}

\section{ARTICLE INFO ABSTRACT}

Article History:

Received 9 November 2018

Accepted 7 Desember 2018

Available online 1 January 2019

\section{Keywords:}

Electropalting

Coating time

Coating distance

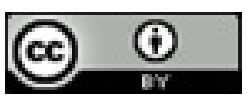

Electroplating is the process of coating an object with other metals that utilizes electricity in electrolyte liquid. In this research the carbon steel as anode material was coated by steel using nickel as catode. The electroplating times and distances of anode catode were varied 6, 9, and 12 minutes and 150, 200, $250 \mathrm{~mm}$. The hardness of the coated materal was evaluated later on by using micro vikers hardness testing. The result indicates that increasing the electroplating time rises the hardness values. The effect of the electroplating time on the harness is significant while the effect of the electrode distance is not.

Dinamika Teknik Mesin, Vol. 9, No. 1, Januari 2019, p. ISSN: 2088-088X, e. ISSN: 2502-1729

\section{PENDAHULUAN}

Electroplating atau pelapisan logam pada dasarnya dilakukan dengan tujuan untuk melindungi permukaan baja dari serangan korosi. Karena logam pelapis tersebut akan memutus interaksi dengan lingkungan sehingga terhindar dari proses oksidasi. Electroplating juga bertujuan untuk menambah keindahan tampak luar suatu benda atau produk. Selain itu dari pelapisan ini akan didapatkan sifat khusus permukaan seperti sifat kekerasan, tahan keausan dan tahan suhu tinggi. Meski demikian di lapangan, produk pelapisan yang dihasilkan lebih banyak digunakan sebagai dekorasi pada kendaraan.

Pengujian bahan material saat ini semakin meluas baik dalam konstruksi, pemesinan, bangunan maupun bidang lain. Hal ini disebabkan karena sifat material yang bisa diubah-ubah. Sejumlah penelitian tentang sifat mekanik material yang dilapisi secara electropalting telah banyak dilakukan. Basmal dkk. (2012) meneliti pengaruh suhu dan waktu pelapisan tembaga-nikel pada baja karbon rendah terhadap ketebalan lapisan dan kekerasan material uji. Dari hasil yang didapat diketahui bahwa ketebalan lapisan tembaga menyamai secara standar teori lapisan material. Hasil pengujian diperoleh tebal lapisan nikel $42,8 \mu \mathrm{m}$ pada suhu $40^{\circ} \mathrm{C}$ dengan waktu pelapisan 10 menit, sedangkan pada suhu $65^{\circ} \mathrm{C}$ dengan waktu 20 menit diperoleh tebal lapisan nikel adalah $65,4 \mu \mathrm{m}$. Sehingga dengan semakin tingginya suhu operasional ketebalan lapisan juga semakin meningkat. 
Material lain selain yang lazim dilapisi adalah krom. Arif dkk. (2015), Musa dan Helmy (2017) meneliti pengaruh waktu pelapisan nikel pada tembaga dalam pelapisan krom dekoratif terhadap tingkat kecerahan dan ketebalan lapisan. Peneliti menggunakan spesimen tembaga berjumlah 15 buah dengan panjang $60 \mathrm{~mm}$ dan diameter $14 \mathrm{~mm}$. Dalam pengujian digunakan tegangan 5 Volt pada temperatur $600^{\circ} \mathrm{C}$ dengan arus $50 \mathrm{~A}$ dan variasi waktu dilakukan $5,10,15,20$ dan 25 menit dengan tiga kali pengulangan. Sedang pada pelapisan kedua variasi waktu pelapisan nikel pada tembaga dilakukan pada range 5 sampai 25 menit. Diperoleh hasil ketebalan pelapisan meningkat, yaitu pada waktu pelapisan nikel 5 menit ketebalanya adalah $14,1 \mu \mathrm{m}$ hingga pada waktu pelapisan 25 menit ketebalanya menjadi $55,77 \mu \mathrm{m}$.

Selain itu ternyata ada juga itu pengaruh pH larutan terhadap massa lapisan material. Febryan dkk. (2012) mengkombinasikan perlakuan pH pencelupan saat pelapisan baja ST 37 menggunakan nikel. yaitu $\mathrm{pH} 3,02,3,23,3,40,3,62,3,82,4,02,4,20$. Analisis data dalam penelitian mereka menggunakan analisis visual. Diperoleh adanya perbedaan massa hasil pelapisan nikel akibat larutan elektrolit dengan variasi $\mathrm{pH}$ pada bahan baja karbon rendah dengan taraf signifikasi sebesar $95 \%$. Mereka menyarankan proses pelapisan nikel dengan menggunakan metode electroplating untuk bahan baja karbon rendah sebaiknya dilakukan pada $\mathrm{pH}$ yang memiliki tingkat keasaman $\mathrm{pH} 3,00$ pada proses lapis nikel.

Selain itu terdapat juga pengaruh arus dan waktu pada pelapisan nikel dengan elektroplating untuk bentuk plat (Sutomo dan Rahmat, 2010). Waktu pelapisan (600, 1200, 1800, dan 2400 detik) dikombinasikan dengan arus listrik yang digunakan (2,5, 4, dan 6 A), Dari beberapa perubahan tegangan dan waktu elektroplating didapatkan hasil pertambahan berat paling tinggi pada arus $6 \mathrm{~A}$. Pada waktu 2400 detik pertambahan berat menjadi 1,52 gr, dan pertambahan berat paling rendah terjadi pada arus 2,5 A dengan waktu 600 detik yaitu sebesar $0,37 \mathrm{gr}$. Jadi hubungan antara arus dan waktu elektroplating sangat berpengaruh terhadap penambahan berat, semakin lama waktu pelapisan dan semakin tinggi arus listrik yang diberikan maka semakin meningkat pula berat benda kerja.

Variasi suhu juga menunjukkan pengaruh yang signifikan terhadap nilai kekerasan material. Erich (2013) dan Setyobudi (2013) menggunakan variasi waktu pencelupan (15, 30, dan 45 menit) dan variasi suhu $\left(300,400\right.$ dan $\left.500^{\circ} \mathrm{C}\right)$. Hasil penelitian menunjukkan bahwa ketebalan lapisan maksimum terdapat pada variasi waktu pencelupan 45 menit, dengan suhu $500^{\circ} \mathrm{C}$ dengan nilai ketebalan 30,6 $\mu \mathrm{m}$. Nilai kekerasan maksimum baja ST 42 diperoleh pada variasi waktu pencelupan 15 menit dengan suhu $300^{\circ} \mathrm{C}$ dengan nilai kekerasan $30,3 \mathrm{HRC}$. Ketebalan dari setiap variasi perlakuan menunjukkan bahwa, waktu dan suhu pelapisan sangat berpengaruh terhadap nilai ketebalan dan kekerasan permukaan.

Pengaruh lain yang diperhitungkan adalah pengaruh konsentrasi larutan dan waktu pelapisan nikel pada aluminium terhadap kekerasan. Pandu (2017), Jhenta dan Khairul (2012) menguji sifat kekerasan baja ST 37 yang dilapisi pada larutan I ( $200 \mathrm{~g} / \mathrm{l}$ nikel sulfat, $175 \mathrm{~g} / \mathrm{l}$ nikel klorida, $40 \mathrm{~g} / \mathrm{l}$ boric acid) dan Larutan II (330 g/l nikel sulfat, $45 \mathrm{~g} / \mathrm{l}$ nikel klorida, $38 \mathrm{~g} / \mathrm{l}$ boric acid). Variasi waktu pelapisan yang divariasikan adalah 10, 15 dan 20 menit. Pengujian kekerasan permukaan menggunakan indentasi mikro vickers dengan pembebanan $10 \mathrm{~g}$. Hasil penelitian mendemonstarsikan bahwa kekerasan permukaan larutan I lebih tinggi dari lapisan II. Hal ini menunjukkan perpaduan senyawa pada media larutan mempengaruhi sifat kekersan material uji.

Untuk mengetahui kualitas suatu material, pengujian kekerasan sangat erat kaitannya dengan kemampuan bahan tersebut menerima beban tertentu. Karena itu, pengujian dalam bentuk pukulan maupun gesekan dilakukan. Namun demikian, optimasi nilai kekerasan permukaan material dengan menggunakan sejumlah variasi perlu dilakukan juga. Parameter yang paling lazim diamati adalah waktu pelapisan yang dikombinasikan dengan parameter lain. Variasi yang belum diujikan adalah waktu pelapisan dan jarak anoda katoda.

Penelitian ini membahas pengaruh waktu elektroplating nikel pada baja karbon rendah terhadap ketebalan lapisan dan kekerasan permukaan dengan mengamati pula jarak antar anoda katoda. Standar pengujian yang digunakan dalam penelitian ini adalah ASTM E384 (10-1000g). Nilai kekerasan permukaan ditentukan berdasarkan persamaan (1).

$$
\begin{aligned}
& H V=\frac{P}{A} \\
& A=\frac{D^{2}}{2 \cos 22}
\end{aligned}
$$


$A$ adalah luas identasi $\left(\mathrm{mm}^{2}\right)$ dan $D$ menyatakan diagonal injakan $(\mu \mathrm{m})$.

\section{METODE PENELITIAN}

Metode penelitian yang digunakan dalam penelitian ini adalah eksperimental. Alat yang digunakan antara lain: rectifier, mesin gerinda potong, mesin bor, mesin polishing, stopwatch, sarung tangan, masker, bak plating, bak pembersih, langsol (batu hijau), amplas besi, mata gerinda kain, dan mikroskop. Sedangkan alat uji yaitu alat uji kekerasan micro hardness tester.

Bahan-bahan yang digunakan pada penelitian ini adalah plat baja (katoda) dengan panjang 100 $\mathrm{mm}$, lebar $30 \mathrm{~mm}$, dan tebal $3 \mathrm{~mm}$ (lihat gambar 1), anoda pelapis (plat Ni), air aquades, dan larutan elektrolit. Komposisi larutan nikel yang dibuat adalah: Nikel Sulfate $\left(\mathrm{NiSO}_{4}\right) 250 \mathrm{~g} / \mathrm{l}$, Nikel Chloride $\left(\mathrm{NiCL}_{2}\right) 250 \mathrm{~g} / \mathrm{l}$, Boric Acid $\left(\mathrm{H}_{3} \mathrm{BO}_{3}\right) 50 \mathrm{~g} / \mathrm{l}$, Brightener NLC-06 1,5 ml/l, Brightener ZD-07 1,5 ml/l. Larutan elektrolit dibuat dengan memanaskan aquades huingga $60^{\circ} \mathrm{C}$, kemudian masukan bahan bahan lainya dan diaduk hingga homogen. Campuran lain yang perlu ditambahkan adalah brightener I-06 dan M-07. Pengujian yang dilakukan pada penelitian ini adalah pengujian kekerasan mikro, sedangkan analisis data menggunakan uji Anova. Pengujian diulang masing masing tiga kali.
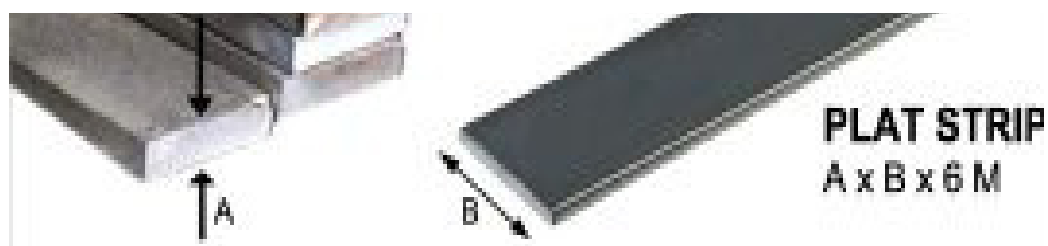

Gambar 1. Plat baja standar yang ada di pasaran

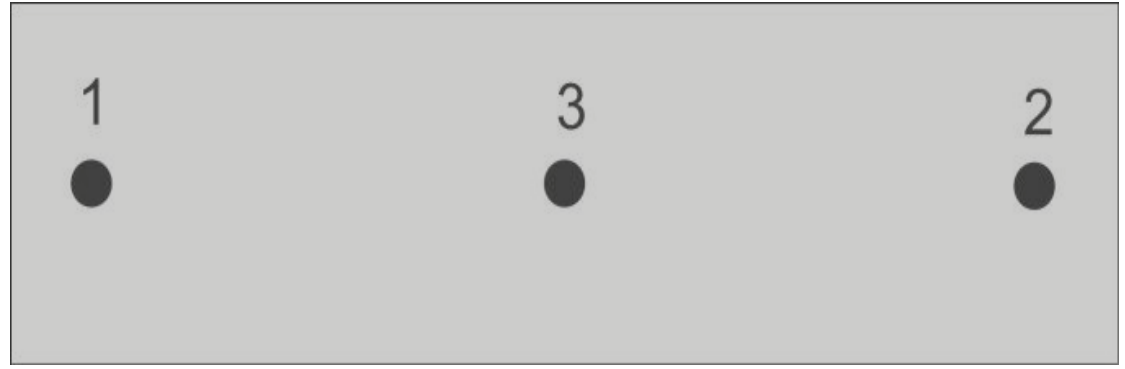

Gambar 2. Titik pengujian pada permukaan spesimen plat katoda.

\section{HASIL DAN PEMBAHASAN}

Dengan menggunakan Persamaan (1) dan (2) nilai kekerasan rata-rata pada spesimen diperoleh dengan masing-masing kode uji mulai dari tanpa pelapisan (TP) hingga kode $A_{n}, B_{n}$ dan $C_{n}$. Nilai kekerasan permukaan pada spesimen A1 misalnya adalah $0,1456 \mathrm{gr} / \mathrm{\mu m}^{2}$ atau $145,6 \mathrm{~kg} / \mathrm{mm}^{2}$. Hasil pengujian kekerasan dari masing-masing variasi lapisan nikel pada baja ST-37 dengan beban identor 50 gram, dan waktu pelapisan 10 detik ditunjukkan pada tabel 1.

Tabel 1. Data hasil pengujian kekerasan permukaan

\begin{tabular}{|c|c|c|c|c|c|}
\hline No. & $\begin{array}{l}\text { Variasi } \\
\text { (menit, mm) }\end{array}$ & $\begin{array}{l}\text { Kode } \\
\text { Spesimen }\end{array}$ & $\begin{array}{l}D \text { indentor rata- } \\
\text { rata }(\mu \mathrm{m})\end{array}$ & $\begin{array}{l}H V \text { rata-rata } \\
\left(\mathrm{kg} / \mathrm{mm}^{2}\right)\end{array}$ & $S$ \\
\hline 1. & 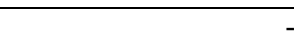 & TP & 25,23 & 145,6 & 0 \\
\hline 2. & 6,150 & A1 & 23,50 & 167,9 & 6,235 \\
\hline 3. & 6,200 & A2 & 23,93 & 161,9 & 2,771 \\
\hline 4. & 6,250 & A3 & 24,35 & 156,7 & 1,401 \\
\hline 5. & 9,150 & B1 & 22,31 & 186,4 & 5,981 \\
\hline 6. & 9,200 & B2 & 23,11 & 173,5 & 0 \\
\hline
\end{tabular}


Dinamika Teknik Mesin. Salman dkk.: Pengaruh waktu dan jarak electroplating nikel pada baja karbon rendah terhadap kekerasan permukaan

\begin{tabular}{rrrrrr}
7. & 9,250 & B3 & 23,51 & 167,7 & 0,173 \\
8. & 12,150 & C1 & 19,45 & 246,7 & 27,931 \\
9. & 12,200 & C2 & 21,82 & 195,3 & 13,00 \\
10. & 12,250 & C3 & 22,48 & 183,5 & 0 \\
\hline
\end{tabular}

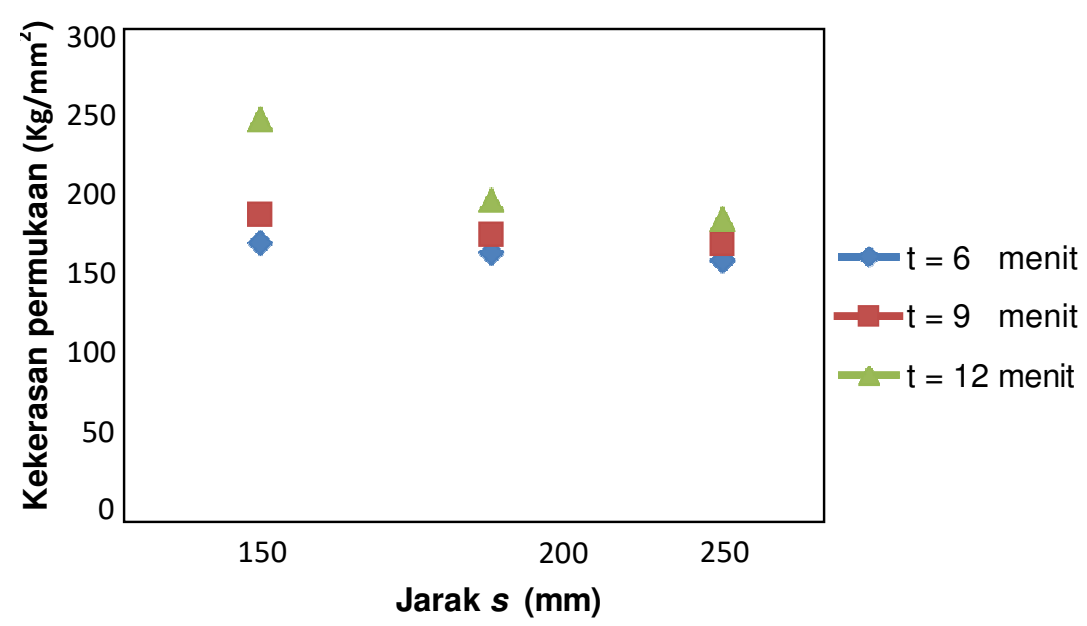

Gambar 3. Nilai kekerasan permukaan material lapisan nikel dengan waktu pelapisan dan jarak anoda katoda berbeda.

Tabel 2. Hasil uji Anova angka kekerasan permukaan.

\begin{tabular}{lcrcccc}
\multicolumn{6}{c}{ Tabel 2. Hasil uji Anova angka kekerasan permukaan. } \\
$\begin{array}{lcrccccc}\text { Source of } \\
\text { Variation }\end{array}$ & SS & df & MS & $F_{\text {hitung }}$ & P-value & $F_{\text {table }}$ \\
& & & & & & \\
\hline Jarak & 7660,88 & 8 & 957,61 & 2,58 & 0,051 & 2,59 \\
Waktu & 6144,41 & 2 & 3072,20 & 8,26 & 0,003 & 3,63 \\
Error & 5948,28 & 16 & 371,77 & & & \\
Total & 19753,56 & 26 & & & & \\
\hline
\end{tabular}

Gambar 3 menunjukkan hasil lapisan nikel dengan variasi waktu pelapisan dan jarak anoda dan katoda didapat nilai kekerasan yang terbaik adalah pada waktu pelapisan 12 menit dengan jarak antara anoda dan katoda $150 \mathrm{~mm}$ yaitu sebesar $246,7 \mathrm{~kg} / \mathrm{mm}^{2}$. Hal ini disebabkan kondisi tersebut merupakan lapisan yang paling tebal sehingga angka kekerasannya juga paling besar. Sedangkan pada waktu pelapisan 6 menit dengan jarak anoda dan katoda $250 \mathrm{~mm}$ diperoleh angka kekerasan paling rendah yaitu $156,7 \mathrm{~kg} / \mathrm{mm}^{2}$. Permukaan pelapisan nikel angka kekerasannya lebih besar dibanding dengan yang tidak dilapisi. Angka kekerasannya sebesar $145,6 \mathrm{~kg} / \mathrm{mm}^{2}$. Meski ada kecenderungan pengaruh jarak antar anoda dan katoda terhadap nilai kekerasan kekerasan baja ST 37 berlapis nikel namun hasil analisis Anova menunjukkan hasil yang berbeda. Hasil statistik Anova dua arah untuk kekerasan permukaan total lapisan nikel dapat dilihat pada tabel 2.

Jarak antar anoda dan katoda $F_{\text {hitung }}=2,575<F_{\text {tabel }}=2,591$ ternyata tidak berpengaruh terhadap kekerasan material, jadi jarak anoda dan katoda pada saat pelapisan tidak berpengaruh terhadap angka kekerasan hasil pelapisan. Untuk waktu pelapisan $F_{\text {hitung }}=8,263>F_{\text {tabel }}=3,633$ berpengaruh, jadi yang berpengaruh terhadap angka kekerasan permukaan dari hasil pelapisan adalah waktu pelapisan saja bukan jarak antar anoda katoda.

Hasil pengamatan menggunakan micro hardness tester menunjukan bahwa angka kekerasan kekerasan pada variasi waktu 12 menit dengan jarak anoda dan katoda $150 \mathrm{~mm}$ sebesar 242,1 $\mathrm{kg} / \mathrm{mm}^{2}$ pada titik pengujian yang pertama dengan diameter indentor sebesar 19,57 $\mu \mathrm{m}$. Variasi waktu 9 menit dengan jarak anoda dan katoda $250 \mathrm{~mm}$ memberikan angka kekerasan sebesar 167,5 $\mathrm{kg} / \mathrm{mm}^{2}$ pada titik pengujian pertama dengan diameter identor sebesar $23,53 \mu \mathrm{m}$. Sedangkan variasi 
Dinamika Teknik Mesin. Salman dkk.: Pengaruh waktu dan jarak electroplating nikel pada baja karbon rendah terhadap kekerasan permukaan

waktu 6 menit dengan jarak anoda dan katoda $150 \mathrm{~mm}$ menghasilkan kekerasan sebesar 175,1 $\mathrm{kg} / \mathrm{mm}^{2}$ pada titik pengujian pertama dengan diameter indentor sebesar 23,01 $\mu \mathrm{m}$.

Hasil percobaan yang dilakukan mengkonfirmasi hasil yang diperoleh Basmal dkk. (2012), Arif dkk (2015), Musa dan Helmi (2017). Meskipun dengan material berbeda yaitu krom, namun terdapat kecenderungan yang sama pada pengaruh waktu pelapisan nikel pada material baik baja karbon rendah ST 37 maupun krom dekoratif terhadap tingkat kekerasan bahan. Hal ini ditunjukkan adanya hubungan linier antara ketebalan lapisan dengan kekerasan oleh Erich, (2013) dan Setyobudi (2013) meski menggunakan satuan kekerasan lain yaitu HRC. Kecendrungan yang sama juga diberikan oleh Sutomo dkk. (2010) yang memperoleh peningkatan berat benda kerja terhadap lamanya waktu pelapisan dengan mengkombinasikan arus listrik electropaliting.

Namun hasil dari percobaan ini menghasilkan nilai kekerasan yang lebih kecil dibanding yang diperoleh Pandu (2017) dan Jhenta dan Khairul (2012). Hal ini karena kedua peneliti tersebut mengoptimasi kinerja paduan senyawa pelarut sehingga mempengaruhi struktur mikro nikel sebagai pelapis baja karbon rendah.

\section{KESIMPULAN}

Hasil percobaan pelapisan baja ST-37 dengan nikel menghasilkan beberapa temuan yang perlu diperhatikan atau menjadi kesimpulan. Semakin lama waktu pelapisan nikel pada baja ST 37, maka angka kekerasan juga semakin besar. Angka kekerasan hasil lapisan nikel dengan waktu pelapisan 12 menit dan jarak antar anoda dan katoda $150 \mathrm{~mm}$, merupakan variasi yang memiliki angka kekerasan paling tinggi yaitu sebesar $246,7 \mathrm{~kg} / \mathrm{mm}^{2}$. Berdasarkan uji Anova, waktu pelapisan sangat berpengaruh terhadap angka kekerasan permukaan, tetapi jarak pelapisan tidak berpengaruh terhadap angka kekerasan permukaan.

\section{UCAPAN TERIMAKASIH}

Penulis mengucakan terimakasih kepada semua pihak yang membantu baik berupa materi maupun pikiran sehingga penelitian dan paper ini dapat terselesaikan. Penulis mengapresiasi Jurusan Teknik Mesin, Universitas Mataram dan Laboratorium Teknik Material dan Metalurgi Institut Teknologi Sepuluh November atas fasilitas yang dipergunakan dalam penelitian ini.

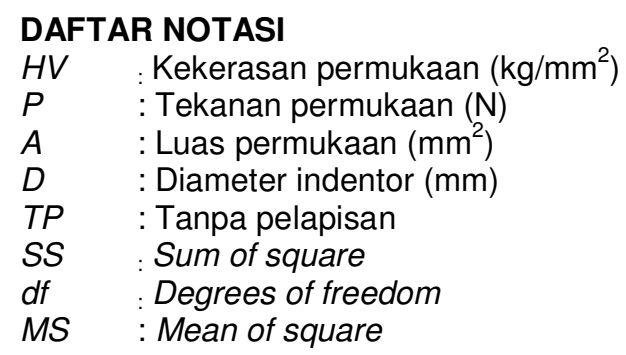

\section{DAFTAR PUSTAKA}

Arif S., Darmawan D.P., Okariawan I.D.K., Sari N.H., 2015, Pengaruh variasi kuat arus listrik dan waktu proses electroplating terhadap kekuatan tarik, kekerasan dan ketebalan lapisan pada baja karbon rendah dengan krom, Dinamika Teknik Mesin: Jurnal Keilmuan dan Terapan Teknik Mesin, 5 (2), 66-72.

Basmal B., Athanasius P.B., Sri N., 2012, Pengaruh suhu dan waktu pelapisan tembaga-nikel pada baja karbon rendah secara elektroplating terhadap nilai ketebalan dan kekasaran, e-journal Undip, 14(2), 23-28.

Erich B., 2013, Pengaruh variasi waktu elektroless pelapisan nikel pada plastik abs dengan metode elektroless plating terhadap karakteristik, Jurnal Teknik Mesin Lintas Jalur Universitas Semarang, 3(7), 13-16.

Febryan A., Fredina D., Eni S., Munasir, 2012, Pengaruh pH larutan elektrolit terhadap tebal lapisan elektroplating nikel pada baja ST 37, Jurnal Penelitian Fisika dan Aplikasinya (JPFA), 2(2), 4852.

Jhenta D., Khairul A., 2012, Dampak variasi tegangan listrik pada proses pelapisan hard anodizing terhadap laju korosi aluminium, Tugas Akhir, Universitas Brawijaya.

Musa A., Helmy P., 2017, Pengaruh tegangan pelapisan nikel pada tembaga dalam pelapisan khrom dekoratif terhadap ketebalan, kekerasan dan kekasaran lapisan, momentum, 13(2), 19-24 
Pandu A., 2017, Analisa variasi tegangan dan waktu pelapisan logam nikel terhadap kekerasan baja karbon rendah, Jurnal Mahasiswa, Unesa, (5)1,135-38.

Setyobudi D., 2013, Pengaruh variasi tegangan dan arus pada hard anodizing alumunium 6061 terhadap ketebalan dan kekerasan permukaan untuk katoda titanium dan konsentrasi larutan H3PO4, 3 mol. Jurnal Momentum, 2(1), 19-24.

Sutomo S., Rahmat, 2010, Pengaruh arus dan waktu pada pelapisan nikel dengan elektroplating untuk bentuk plat, Jurnal Metana, 6(2), 13-17. 